\title{
UK's long-held scepticism of European space plans
}

\section{London}

BRITAIN's scepticism of the proposed long-term programme of the European Space Agency (ESA) to be debated by ministers at The Hague next week is not confined to members of the government. Officials at the British National Space Centre (BNSC) have also become concerned at the escalating costs of the programme and the questionable merit of heavy investment in manned projects.

It has been widely assumed that it was

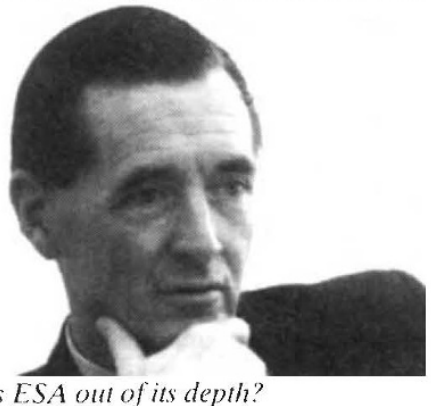

Gibson - is ESA out of its depth?

solely government parsimony that prompted Britain's objections. But last week Mr Roy Gibson, the former director-general of BNSC who resigned in August after the government refused to increase the space budget, told the House of Lords Select Committee on Science and Technology that during discussions with ESA officials over the past 18 months, UK delegates have consistently warned that the proposed programme is too ambitious.

According to Gibson, the rapid evolution of ESA's programme takes it well beyond the bounds set by ministers in Rome in 1985. Gibson feels that ESA is biting off more than it can reasonably chew. "We have had the feeling that ESA has not realized the extent of the commitment it was taking on."

One of the main concerns expressed by $\mathrm{UK}$ delegates is the growing imbalance in the programme in favour of large infrastructure projects at the expense of user programmes. Gibson questions the accuracy of some of ESA's cost-of-completion studies, in particular that of the Hermes space vehicle. Initially, ESA quoted $£ 2,000$ million; Gibson, who describes Hermes as "a luxury", argued that the true cost would be nearer $£ 7,000$ million. ESA has since revised its estimate to $£ 4,000$ million. Gibson feels that complete package ESA's will not be adopted.

\section{Nobel error}

IN “MIT needs millions" (Nature 329, 757; 1987) the 1987 Nobel prize for economics was mistakenly awarded to David Saxon, MIT's chairman.

The real recipient is, of course, Professor Robert M. Solow of the same institute. but that a seriously imbalanced programme could nevertheless emerge.

It is ironic that Gibson's view of the ESA proposals coincides with that expressed by the government, which still refuses to increase the $\$ 116$ million Britain now spends annually on civil space research.

Simon Hadlington

British ministers are generally badly equipped to determine the guidelines of space policy, the systems used by Whitehall for garnering technical advice are imperfect and most officials have little grounding in the scientific and technical substance, claims a study by the Royal Institute of International Affairs, published this week*. "Space policy has been only one of many examples of drift and confusion in policy-making for science and technology, compounded by the sheer difficulty of comprehending what was at stake."

The report says the country's fragmented approach to space policy and its failure to demonstrate commitment to international collaborations has prevented it from exploiting technological and political advantages.

The report warns that if Britain does not increase its contribution to ESA it will not be able to retain the national capabilities it would need if security interests and technological developments began to favour a larger military programme, either nationally or within a European context. "Britain cannot expect to retain an effective capability in space at the current level of engagement . . . . Space has far-reaching implications for British economic modernization as well as for Britain's foreign and security policies."

British Space Policy and International Collaboration. (Royal Institute of International Affairs, Londion. £6.95.)

\section{Protests in South Africa over threatened subsidy cuts}

Cape Town

THOUSANis of students, staff and alumni took part in general assemblies at South African universities on 28 October to protest at the imposition of the subsidy conditions promulgated on 9 October by the Minister of National Education, $\mathrm{Mr}$ F.W. de Klerk. Assemblies were held at the Universities of the Witwatersrand, Cape Town, Western Cape, Natal and Westville, and at Rhodes University the previous week.

Academic processions round the perimeter of each campus were held without incident, except at the University of the Witwatersrand where riot police baton-charged students at the edge of the campus in Johannesburg's Jorrissen Street. At the Universities of Cape Town and the Western Cape, exits from the campus were manned by police and at Western Cape police helicopters circled over the 5,000-strong procession.

These protests form part of a joint response to the subsidy conditions. In August, the universities were asked to respond to a set of government proposals requiring university councils to prevent various kinds of political activity on campuses, including specifically interference with academic activities, unlawful gatherings, promotion of strikes, boycotts or work stay-aways, actions of civil disobedience or the printing of any publication in contravention of the internal Security Act. These proposals were rejected by several of the country's universities (see Nature 329, 192; 1987). This opposition has been largely ignored by de Klerk, as the new regulations are virtually the same as his original proposals, with the exception of a provision curbing "affected" organizations, which has been omitted. The universities are said to be considering appealing to the courts to declare the regulations ultra vires. The regulations themselves are not enshrined in an act of parliament, and have been promulgated by the minister in terms of the Universities Act, 1955.

The rector of Pretoria University, Professor Danie Joubert, said that he was not particularly concerned about the regulations, as he was happy that the government intended to accede to his request that it "acknowledge the authority of the university council". He had received assurances that in the event of a contravention of the regulations, the government would not unilaterally impose a subsidy cut, but would first enter into consultation with the university concerned.

The president of the Council for Scientific and Industrial Research, Dr Chris Garbers, said that he did not feel that he was in a position to comment on the regulations, as he had not been a party to the negotiations between the government and the universities and therefore did not have first-hand knowledge of all the relevant details.

Meanwhile, at Stellenbosch University, about 200 students marched to the office of the rector, Professor Mike de Fries, to deliver a protest deploring his acceptance of the regulations, which it described as "an attempt by the government to turn the universities into instruments to sustain the National Party idea of law and order".

Michael Cherry 